\title{
CULTURAL VALUE OF THE LITERATURE TRANSLATION IN MIGRANT INTEGRATION PROCESSES
}

\author{
Oksana Tereshchenko ${ }^{1}$ \\ ${ }^{1}$ Department of Philosophy, National Technical University of Ukraine «Igor Sikorsky Kyiv Polytechnic Institute», Kyiv, Ukraine \\ perekladachgr@gmail.com \\ ORCID: http://orcid.org/0000-0002-0856-6370
}

ARTICLE INFO

Article history:

Received date 03.12.2019

Accepted date 20.12.2019

Published date 31.01.2020

Section:

Linguistics

D O I

10.21303/2313-8416.2020.001151

KEYWORDS

migrant

integration

literary translation, social environment

author

reader

interdisciplinary approach

intercultural communication

\begin{abstract}
The article deals with the importance of speech transmissions in the integration processes of socialization of migrants of the foreign social environment. The text explores the exchange of literary and cultural heritage and the philosophical context of being in a foreign environment. It has been proved, that the translation problem deserves a socio-philosophical perspective and at the same time requires an interdisciplinary approach. This topic is closely related to the general issues of intercultural communication: the ability to listen, to empathize and logically formulate their own thoughts to an interlocutor. Identified the specific "Translator Toolkit" of a translator, the specifics and socio-cultural components of the activity and the peculiarities of creating the "Writer-Translator-Reader" Polylogue, disclosed the main determinants and their solutions for the effective integration of the migrant into the culture of a foreign state through translation literature as a factor of infusion into the social environment.
\end{abstract}

(C) The Author(s) 2020. This is an open access article under the CC BY license http://creativecommons.org/licenses/by/4.0).

\section{Introduction}

The translation activity is not enough studied in philosophical reflection today. Studies of this direction have a lot of gaps together with numerous shortcomings in setting contacts in the literature field namely - in the interaction between creative unions of Ukrainian and Greek writers. And language aspects are not studied at all, in particular, literature translation is little studied, especially the language combination: Ukrainian - Modern Greek - Ukrainian languages [1]. But it is extremely urgent for emigrants, who went abroad for any cases. In this paper we'll consider such important topics as: the importance of speaking translations in integration processes of migrant's socialization in a foreign social space, we'll demonstrate the exchange of literature-culture achievements of the countries, we'll prove that the problem of translations is worthy of the social-philosophical perspective and at the same time needs an interdisciplinary approach, we'll demonstrate that this subject is closely connected with general questions of intercultural communication, we'll determine the concrete "toolkit" of a translator, we'll discover main determinants of the effective integration of a migrant in a foreign state culture due to the translation literature as a factor of penetration the social space.

For integrating a foreign space, a migrant must first of all to plunge into another environment and thinking-speaking. For understanding the culture of another nation, its values, to comprehend the life, manners and customs of a country, a migrant must, first of all, to familiarize translations of masterpieces of the world level. The foreign outstanding poetic composition of Cretan literature of Middle Ages "Erotocritos" by V. Kornaros in the Ukrainian translation of V. Stepanenko, edited this year, that presents extremely brightly the history, life, customs and manners of the Greek nation of the certain period, may serve an example. Communication and setting of intercultural connections, especially between Greece and Ukraine, is one of main components of literature translation. It is necessary to set a certain "language bridge", due to which the full involvement in another environment and step-by-step setting of connections between two countries is possible, and a migrant must give a useful contribution in the cultural development of both states.

\section{Literature review}

Last studies and publications show us that the need in translation activity increases at the background of growing international contacts and global migration of the population. And for sat- 
isfying the interest of nations in each other, people must set the exchange of cultural values. The authors just indicate: "The analysis of intercultural communication just in interconnection with the science about translation allows to consider the question of the role of translation in setting the adequate individuals' comprehension of each other and information that must be given and to save the national and cultural identity at that" [2].

In Ukraine studies of the problematic of intercultural communication is still only at the formation stage, but gains more importance year by year because of globalization processes and intensive migration of Ukrainians [2]. The term "intercultural communication" is related to the notion "dialog of cultures" and accents the formation of the new social space of culture and forms of free communication of people in it. Because just by the way of cultures dialog there takes place the identity, mutual understanding, interaction and mutual enrichment of nations [4]. The other author presents the term "intercultural communication" as a social phenomenon that is in a constructive or destructive interaction between representatives of different cultures within a distinctly outlined spatial-temporal continuum, where a person as a bearer of cultural peculiarities is in the center of intercultural interactions [5].

All these notions - "dialog of cultures", "intercultural communication", "translation activity" - are closely interconnected. Translation crates the world community, spiritually integrates and consolidates humankind, making separate achievements of nations the general contribution. There takes place the intercultural communication - dialog of cultures. At the same time translation guards its own language, is a bearer of its own traditions, culture, originality [6]. Just translation, especially the written one, is used as a channel of the book or literature communication, through which the dialog of cultures, civilizations and the exchange of these achievements also take place $[7,8]$.

These studies show us that literature translation and its culture-creating potential plays the important role in life and integration involvement of a migrant into a foreign environment. The aforesaid authors correctly described the subjects from the theoretical point of view, but the problem is that these questions must be studied "from inside". Just a person, who felt these problems in practice and was personally involved in the migrant environment, felt migrant life problems on his/her own, can define determinants of integration in a foreign space more practically. There is a sense to define a concrete "toolkit" of a translator, the specificity and socio-cultural components of his/her activity and peculiarities of creation of the "author-translator-reader" polylogue $[9,10]$.

«There is expressively traced in translation studies the philosophical-culturological approach to the phenomenon of art translation. The formulation of the problem of art translation as not especially linguistic, but also in the wide understanding as the sign transformation at different associative-cultural levels causes a lot of worldview-philosophical problems that must be today comprehended by representatives of most influential schools of translation studies" [3].

\section{Aim and tasks of research}

The aim of the research is to prove the intercultural creative value and powerful potential of translation, especially of the literature one, in the integration process of migrants' socialization, to discover the mission of translators' and writers' unions in Ukraine and Greece in assisting migrants in their attempts to familiarize themselves in the foreign space, to report actual knowledge in the field of language, history, life, customs and manners, understanding of mentality of the nations.

The following tasks were set for attaining this aim:

1. To study the importance of speaking translations in integration processes of migrants' socialization in the foreign social space.

2. To demonstrate working methods and originality of a translator in migrants' integration.

3. To determine functions of translation and their importance in the culture-creative space.

4. To study how the notions "dialog of cultures", "translation activity" and "intercultural communication" are connected with each other and influence integration process of migrants' socialization.

5. To explain the term "language originality, "exclusive language" and to study peculiarities of the translation process in the activity of Ukrainian and Greek writers.

6. To determine, what is migrants' integration, what it is needed for, and its main functions. 
7. To prove the importance of the inrush in literature circles of Ukraine and Greece, the mission of writers' and translators' unions of Ukraine and Greece in familiarization of the foreign space, languages, history, mentality by migrants due to the translation activity.

\section{Materials and methods}

Translation is a distinct presentation of a certain material by another language. Literature translation is a mirror reflection of a literature work by another language with keeping logic, melody and spiritual richness of a text. Translations are certainly written and oral. Oral translation is difficult, because a translator must orient in situations fast, a certain expensive apparatuses are needed in some cases, translator's services are usually rather expensive, especially, in case of such rare language as Modern Greek. Written translation has its advantages, because there is a possibility to think, to spend time, to use vocabularies. If it concerns a translation from a foreign language into the native one - it is a simpler variant, but if there is a translation from the native language into a foreign one - it is a great flow of work with attaching certain functions and assistants, and not every translator can cope with it well. But the global mission of a literature translator is in setting bridges of interaction and mutual enrichments of cultures of the world nations. It is a powerful instrument of communication and reporting of a cultural heritage and lifestyle, thinking to another speaking reader, migrant, instrument of the intensive entrance to another speaking space. A translator can perform his/her exclusive mission for transfer through translation and to give a migrant all necessary information, its mental layers as full as possible for the intensive integration in the environment.

The certain translation functions are used for that: assessing-educative, cognitive, general cultural, communicative and social. The assessing-educative function of translation is oriented on absolute general human values, the cognitive one is realized through cognition, studying of the surrounding world, the general cultural is connected with an esthetic context, the communicative function is in the mean of intercultural communication, the social one is traced in texts and spheres of political, cultural, economic cooperation between cultures of different nations [11].

That is why, the notions "dialog of cultures", "translation activity" and "intercultural communication" have the common component. The intercultural communication is impossible without the translation activity, and the cultures dialog is impossible without communication. It especially concerns exclusive that is rare languages, in particular, Modern Greek one.

For today only works of T. Shevchenko and several other classics of Ukrainian literature are partially translated from Ukrainian into Modern Greek. A translation of Ukrainian leading writers and the more so modern prosaists and poets is absent in Greece. It is caused by the exclusive character of the Modern Greek language, its complicacy and lack of high-quality translators from Ukrainian to Modern Greek and from Modern Greek to Ukrainian (according to reports of the National union of writers of Ukraine and the article by Nataly Terentieva "UkrainianGreek cultural connections: formation and cultural life of the diaspora in Greece" [13]). But this year practice has demonstrated that due to migration and internal work, this direction has become to progress $[14,15]$. There has begun the exchange of literature achievements due to the National unions of writers of Ukraine and Greece, which initiators are Ilias Papaconstantinou, Oksana Tereschenko and Maria Vorobey. There was conducted a series of mutual festivals, meetings, presentations, made translations of the Ukrainian classics: T. Shevchenko, L. Ukrainka, I. Franko, G. Skovoroda, and also Greek coryphaeuses: Yorgos Seferis, Odysseus Elytis, Nikos Kazantzakis and other - this all is being done and is being planned to do in further. It is necessary to prepare editions of books in two languages, to conduct literary readings in two languages together with migrants, to open literature-translation circles (off- or online) at participation of native writers of different countries and translators-migrants, to set high-quality and close contacts between the countries, to cooperate between unions of literary translators. All these processes and factors will give a migrant a possibility to integrate in the foreign environment, because integration it is a certain involvement of an individual to another society, the full acceptance of its law and rules by him/her and their effective use. And the effective integration is impossible without knowledge about the culture, ethic contribution of another nation and cultural exchange. 


\section{Research results and their discussion}

The translation activity is a necessary component of social integration of migrants. The study of the culture of the society, alien till this time, orientation in the foreign environment facilitate their integration in the foreign social space. Let's note that in June of this year in Kyiv for the first time of independence "The anthology of modern Greek poetry", translated into Ukrainian from Modern Greek by Oksana Tereschenko, was presented in the National Union of Ukrainian Writers in one of antique halls at presence of Greek and Ukrainian modern poets. Greek poets-signers demonstrate in their works the same desires, pain, love, connected by feelings with the Ukrainian today. They are very familiar to a Ukrainian reader. Ukrainian works agitate the Greek audience too. Thus, translations from the Modern Greek language into Ukrainian and presentation in Kyiv inspired poets and the Union of Writers of Greece to create an anthology of Ukrainian poets and to present it in Athens. These events caused a great interest and discussion in the diasporas of Greece and Ukraine among migrants that favored closer connections between the nations, historically connected by thousand years. The embassies of Ukraine and Greece actively support such cooperation and in every way favor the development of intercultural communication of the two nations. Thus, there takes place the exchange of knowledge of the languages, history, custom and manners, understanding of mentality and integration in the cultural-social life of the two countries. It results in novelty and promising prognoses of the study.

At that let's note, that T. Tsymbal writes about a migrant as a tragic personality, living far from the motherland, not uselessly. Emigration becomes a special tragedy for creative persons, artists [12]. But we have another impression from successful Ukrainians, gained a good glory abroad, made a successful career, make a favorite business and enjoy it. We have demonstrated the mission of writers' and translators' unions of Ukraine and Greece in favoring migrants in their integration in the foreign space. But we can agree with T. Tsymbal that nostalgia for the motherland will be always a leading problem of both migrants' life and literary works. So, migrants' entrance in the foreign social space through literary translations and international cultural connections open prospects of philosophical reflection about migrant's personal socialization and his/her socio-cultural evolution.

\section{Conclusions}

1. The importance of speaking translations in integration processes of migrants' socialization in the foreign social space has been studied. A conclusion can be made that speaking translations positively influence the development and fast integration of migrants in the foreign environment.

2. The translator's working methods have been demonstrated and originality in the process of migrants' integration has been proved. These methods gave migrants a possibility to feel themselves more confident in the foreign environment, to understand how to act in certain situations.

3. The translation functions and their importance in the culture-creating space: assessing-educative, cognitive, general cultural, communicative and social that help migrants to orient in both Greece and Ukraine, to integrate and to be useful for a society have been determined.

4. It has been explained how the notions "dialog of cultures", "translation activity" and "intercultural communication" are connected with each other and influence the migrants' integration process. Such notions as "dialog of cultures", "translation activity" and "intercultural communication" have the common component. The intercultural communication is impossible without the translation activity, and the cultures dialog is impossible without communication. The intercultural communication is impossible without the translation activity, and the cultures dialog is impossible without communication.

5. The term "exclusive language" is explained. There is also studied the translation process on the examples of Ukrainian and Greek writers in the foreign translation. Exceptional or "exclusive language" is a rare one. And it is very useful, when Ukrainian emigrants depart for any cases to such countries as, for example, Greece - it is important to facilitate integration in the society by the translation activity, by both oral and written translation.

6. Migrants' integration it is the entrance and adaptation of an individual in the foreign space, it is needed for the full-value communication by studying the language, culture, customs and manners for being useful for both foreign society and native country. This definition is very 
useful for Ukrainian migrants for deciding either stay in the foreign country or to return back in Ukraine with time.

7. Due to the inrush in literary circles of Ukraine and Greece, we have proved the novelty of this study and importance of speaking translations in integration processes of migrants' socialization in the foreign social space. We have shown the exchange of literature-culture achievements of the countries. We have proved that the problem of translations is worthy of the social-philosophical perspective and at the same time needs the interdisciplinary approach

\section{References}

[1] Terentieva, N. (2009). Ukrainsko-Hretski kulturni zviazky: formuvannia ta kulturne zhyttia diaspory v Hretsii. Mizhnarodni zviazky Ukrainy: naukovi poshuky ta znakhidky, 18. Available at: http://chtyvo.org.ua/authors/Terentieva_Nataliia/Ukrainskohretski_kulturni_zviazky_formuvannia_ta_kulturne_zhyttia_diaspory_v_Hretsii/

[2] Borzykh, O. O., Huk, I. S. (2014). Rol perekladu u protsesi mizhkulturnoho spilkuvannia. Naukovi zapysky NDU im. M. Hoholia. Filolohichni nauky, 3, 31-32.

[3] Bibler, B. C. (1989). Kultura. Dialog kultur (opyt opredeleniia). Voprosy filosofii, 6, 31-42.

[4] Podolska, Ye. A., Lykhvar, V. D., Ivanova, K. A. (2003). Kulturolohiia. Kyiv: Minokhoronzdrav Ukrainy. Nats. farmatsevtych. un-t, 287.

[5] Markyna, M. H. (2008). Adekvatnost kak perevodcheskaia problema (funktsyonalnii podkhod). Visnyk Dnipropetrovskoho universytetu. Seriia: Movoznavstvo, 16 (14), 184-189.

[6] Cherednychenko, O. I. (2007). Pro movu i pereklad. Kyiv: Lybid, 248.

[7] Miram, G. E. (1999). Professiia: perevodchik. Kyiv: Nika-Centr, 160.

[8] Galperin, I. R. (1981). Tekst kak obekt lingvisticheskikh issledovanii. Moscow: Nauka, 138.

[9] Simeoni, D. (1998). The pivotal status of the translatores habitus. Target International Journal of Translation Studies, 10, 1-39. doi: http://doi.org/10.1075/target.10.1.02sim

[10] Kolomiiets, L. V. (2011). Perekladoznavchi seminary: aktualni teoretychni kontseptsii ta modeli analizu poetychnoho perekladu. Kyiv: Kyivskyi universytet, 527.

[11] Burdè, P. (2007). Socialnoe prostranstvo: polia i praktiki. Saint Petersburg: Aleteiia, 567.

[12] Tsymbal, T. (2012). Fenomen emihratsii: dosvid filosofskoi refleksii. Kyiv-Kryvyi Rih, 396.

[13] Tereshchenko, O. (2019). Krytychnyi ohliad hretskoi zhinochoi prozy. Kultura i zhyttia, 27.

[14] Tereshchenko, O. (2019). Apollona nezghasaiuche svitlo. Literaturna Ukraina, 6-7.

[15] Vermeer, H. J. (1987). What does it mean to translate? Indian Journal of Aplied Linguistics, 13 (2), 25-33. 